\section{(2) \\ BRAZIULIAN JOURNAL \\ OF MEDICAL AND BIOLOGICAL RESEARCH}

www.bjournal.com.br
ISSN 1414-431X

Volume 45 (11) 995-1101 November 2012

BIOMIEDICAL SCIENCES

AND

CLINICAL INVESTIGATION

Braz J Med Biol Res, November 2012, Volume 45(11) 1002-1010

doi: $10.1590 / \mathrm{S} 0100-879 \mathrm{X} 2012007500132$

Simultaneous allergen inactivation and detoxification of castor bean cake by treatment with calcium compounds

K.V. Fernandes, N. Deus-de-Oliveira, M.G. Godoy, Z.A.S. Guimarães, V.V. Nascimento, E.J.T. de Melo, D.M.G. Freire, M. Dansa-Petretski and O.L.T. Machado

The Brazilian Journal of Medical and Biological Research is partially financed by

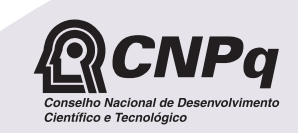

da Ciência e Tecnologia

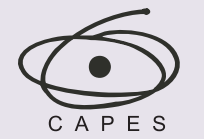

Ministério da Educação
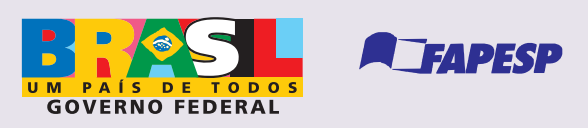

Institutional Sponsors

sureto
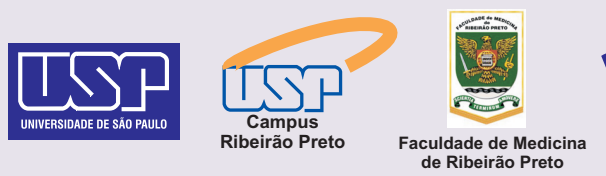

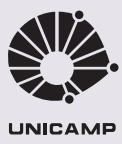

SHIMADZU

Associaçăa
Fundo de Incentivo
à Pesquisa

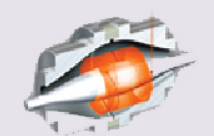




\title{
Simultaneous allergen inactivation and detoxification of castor bean cake by treatment with calcium compounds
}

\author{
K.V. Fernandes ${ }^{1}$, N. Deus-de-Oliveira1 ${ }^{1}$, M.G. Godoy ${ }^{3}$, Z.A.S. Guimarães ${ }^{2}$, \\ V.V. Nascimento ${ }^{1}$, E.J.T. de Melo ${ }^{2}$, D.M.G. Freire $^{3}$, M. Dansa-Petretski ${ }^{1}$ \\ and O.L.T. Machado ${ }^{1}$ \\ ${ }^{1}$ Laboratório de Química e Função de Proteínas e Peptídeos, Centro de Biociências e Biotecnologia, \\ Universidade Estadual do Norte Fluminense Darcy Ribeiro, Rio de Janeiro, RJ, Brasil \\ 2Laboratório de Biologia Celular e Tecidual, Centro de Biociências e Biotecnologia, \\ Universidade Estadual do Norte Fluminense Darcy Ribeiro, Rio de Janeiro, RJ, Brasil \\ ${ }^{3}$ Laboratório de Biotecnologia Microbiana, Instituto de Química, Universidade Federal do Rio de Janeiro, \\ Rio de Janeiro, RJ, Brasil
}

\begin{abstract}
Ricinus communis L. is of great economic importance due to the oil extracted from its seeds. Castor oil has been used for pharmaceutical and industrial applications, as a lubricant or coating agent, as a component of plastic products, as a fungicide or in the synthesis of biodiesel fuels. After oil extraction, a castor cake with a large amount of protein is obtained. However, this by-product cannot be used as animal feed due to the presence of toxic (ricin) and allergenic (2S albumin) proteins. Here, we propose two processes for detoxification and allergen inactivation of the castor cake. In addition, we establish a biological test to detect ricin and validate these detoxification processes. In this test, Vero cells were treated with ricin, and cell death was assessed by cell counting and measurement of lactate dehydrogenase activity. The limit of detection of the Vero cell assay was $10 \mathrm{ng} / \mathrm{mL}$ using a concentration of $1.6 \times 10^{5}$ cells/well. Solid-state fermentation (SSF) and treatment with calcium compounds were used as cake detoxification processes. For SSF, Aspergillus niger was grown using a castor cake as a substrate, and this cake was analyzed after 24, 48, 72, and $96 \mathrm{~h}$ of SSF. Ricin was eliminated after $24 \mathrm{~h}$ of SSF treatment. The cake was treated with 4 or $8 \% \mathrm{Ca}(\mathrm{OH})_{2}$ or $\mathrm{CaO}$, and both the toxicity and the allergenic properties were entirely abolished. A by-product free of toxicity and allergens was obtained.
\end{abstract}

Key words: Ricinus communis; 2S albumin; Ricin; Biodiesel fuel; Solid-state fermentation; Vero cells

\section{Introduction}

The castor plant (Ricinus communis) is an oleaginous plant that has been cultivated since ancient times. Today, the demand for the oil of this plant is rising in response to incentive programs for biodiesel production, which means that the production of the castor cake by-product after oil extraction is also increasing. Castor cake is currently used in fertilizers (1). Although these castor cakes are rich in protein and fiber, the presence of toxic compounds limits their use as an animal feed, and the presence of allergenic proteins could cause health problems for workers who manipulate these seeds or cakes.
The main toxic component of castor cake is ricin, a protein found exclusively in the endosperm of castor seeds. Ricin is classified as a type 2 ribosome-inactivating protein (2). Recently, Leshin et al. (3) demonstrated that the $R$. communis genome encodes seven full-length ricin family members, and all encoded ricin-like proteins can hydrolyze the adenine in $28 \mathrm{~S}$ ribosomal RNA ( $r R N A$ ) and may contribute to the toxicity of castor seeds. Ricin is a 66-kDa protein composed of two functionally different chains linked by a disulfide bridge. The ricin A chain is a $32-\mathrm{kDa}$ polypeptide (4) with glycosidase activity, which removes an adenine

Correspondence: O.L.T. Machado, Laboratório de Química e Função de Proteínas e Peptídeos, Centro de Biociências e Biotecnologia, Universidade Estadual do Norte Fluminense Darcy Ribeiro, Av. Alberto Lamego, 2000, 28013-602 Rio de Janeiro, RJ, Brasil.

Fax: +55-22-2739-7131. E-mail: olgauenf@yahoo.com.br

Received April 3, 2012. Accepted August 2, 2012. Available online August 24, 2012. Published October 5, 2012. 
residue from a loop region of rRNA (5). This rRNA loop is essential for elongation factor binding; therefore, the modified ribosomes cannot support protein synthesis (6). Ricin is so efficient that one molecule of the A chain can inactivate approximately 1500 ribosomes per minute (7). For decades, researchers have attempted to eliminate ricin from the castor cake. Anandan et al. (8) reported that autoclaving (15 psi, $60 \mathrm{~min}$ ) and alkali treatment completely destroyed the toxin, as evaluated by electrophoresis; however, toxicological assays were not performed in their study.

Our group has developed a low-cost process for the biodetoxification of castor waste (the residue generated during biodiesel fuel production process, such as that developed by Petrobras, the national petroleum company of Brazil) (9). This extremely alkaline waste is toxic and allergenic and, as such, poses a significant environmental problem (9). In a previously reported process, this alkaline toxic waste was used as a source for the growth of the fungus Penicillium simplicissimum, and the solid-state fermentation conditions were adjusted to produce lipases (9).

Despite the existence of several processes for castor cake detoxification, there are no standardized methods to validate them. In a recent review, Severino et al. (10) presented several methodologies for the detection of ricin, including methods based on the survival rate of animals (11), cell-free and cell-based cytotoxicity assays (12), SDSPAGE (8), an enzyme-linked immunosorbent assay (13), fluoroimmunoassays, and immuno-PCR $(14,15)$; however, the measurement of relative ricin toxicity remains a challenge for the scientific community working on this protein.

In contrast to the existence of several processes for castor cake detoxification, no method is available for the inactivation of the allergenic fraction, although the primary structures of the major allergens present in the $2 \mathrm{~S}$ albumin pool, Ric c 1 and Ric c 3, have been determined (16-19). In this study, we describe processes that simultaneously detoxify and inactivate the allergens present in castor beans. We adapted the methodology for the detection of ricin toxicity as previously described (20) and used it to assess the efficiency of bioprocessing or the chemical treatments proposed. We measured the degranulation of mast cells and the release of histamine in rats to evaluate allergenic activity in another assay.

\section{Material and Methods}

\section{Plant material and ricin purification}

Castor seeds were obtained from Instituto Agronômico de Campinas, Campinas, SP, Brazil, and ricin was isolated by the procedure of Anandan et al. (8), as described below.

Castor cake $(500 \mathrm{~g})$ was extracted with $2.5 \mathrm{~L}$ water acidified with $\mathrm{HCl}$ to a $\mathrm{pH}$ of 3.8 by shaking the contents in a conical flask for $6 \mathrm{~h}$. The contents were allowed to settle and were then filtered through Whatman filter paper No. 1.
The residue was treated with $1.5 \mathrm{~L}$ distilled water, shaken for $3 \mathrm{~h}$, and filtered through the same paper. The residue was treated a second time with water and filtered again through the same filter paper. This filtrate contained all the ricin and portions of ricinine that are soluble in cold, dilute $\mathrm{HCl}$. It was evaporated to a small volume using vacuum distillation at a temperature below $40^{\circ} \mathrm{C}$. The filtrate was saturated with sodium chloride and centrifuged at $2800 \mathrm{~g}$ for $20 \mathrm{~min}$ to separate the precipitate containing only ricin. The homogeneity of the isolated fraction was evaluated by SDS-PAGE (10 $\mu \mathrm{g} / \mathrm{slot})$ and the N-terminal partial sequence of the only band obtained was determined by automated sequencing using a PPSQ-33A Protein Sequencer from Shimadzu (Japan).

\section{Ricin detection by cytotoxic assay}

Purified ricin was used at various concentrations (100, 10 , and $1 \mu \mathrm{g} / \mathrm{mL}, 100,10$, and $1 \mathrm{ng} / \mathrm{mL}, 100$ and $10 \mathrm{pg} /$ $\mathrm{mL}$ ) to determine the detection limit of the assay. Vero cells (Chlorocebus sabaeus kidney cells) were cultivated in culture flasks and grown at $37^{\circ} \mathrm{C}$ in Dulbecco's modified Eagle's medium (DMEM) supplemented with $5 \%$ fetal bovine serum and penicillin-streptomycin. The cells were detached from the flasks by treatment with Trypsin $(0.5 \mathrm{mg} / \mathrm{mL})$ with $\operatorname{EDTA}(0.2 \mathrm{mg} / \mathrm{mL})$ in PBS for $5 \mathrm{~min}$ at $37^{\circ} \mathrm{C}$. The detached cells were suspended in the growth medium, incubated in a 24-well plate at a concentration of $2.0 \times 10^{4}$ cells/well and maintained at $37^{\circ} \mathrm{C}$ for $48 \mathrm{~h}$ before use. The ricin dilutions were first sterilized by passage through a $0.22-\mu \mathrm{m}$ pore filter and then added to the cells. Each dilution was tested in triplicate. The initial cell concentration was $1.6 \times 10^{5} \mathrm{cells} /$ well. Cells incubated with PBS, pH 7.0, were used as a negative control, and $2 \%$ Triton $\mathrm{X}-100$ was used as a positive control. To determine the toxicity, we counted the cells at 40X magnification, and performed a lactate dehydrogenase $(\mathrm{LDH})$ activity assay. Cell death was measured using the Cytotoxic Detection Kit from Roche (Germany) after 24 and $48 \mathrm{~h}$ of incubation. The cell culture supernatant $(100 \mu \mathrm{L})$ was placed in each well of a 96-well plate, followed by the addition of $100 \mu \mathrm{L}$ LDH detection solution, and incubated in the absence of light for $30 \mathrm{~min}$ at room temperature. The colored product was measured using a Thermo plate reader with absorbance set at $490 \mathrm{~nm}$. Cytotoxicity was calculated following the instructions provided by the manufacturer kit. Each sample was tested in triplicate.

To confirm that the toxicity was specifically due to the presence of ricin, a ricin anti-A chain (goat lgG) antibody was added to the incubation solution $(8 \mu \mathrm{g} / \mathrm{mL})$. These antibodies were administered to cells in culture $\left(1.6 \times 10^{5}\right.$ cells/well) along with $1 \mu \mathrm{g}$ ricin $/ \mathrm{mL}$.

\section{Solid-state fermentation}

To obtain fungal spores, Aspergillus niger was propagated at $30^{\circ} \mathrm{C}$ for 7 days in a potato dextrose agar medium supplemented with $1.0 \%$ olive oil. The spores were sus- 
pended in $100 \mathrm{mM}$ phosphate buffer, $\mathrm{pH} 7.0$, and counted in a Neubauer chamber.

A castor cake was used as the solid-state fermentation culture medium. The meal was ground in a laboratory knife mill and separated in a sieve shaker (W.S. Tyler 14 sieve, USA). The final meal particle sizes were less than $1.18 \mathrm{~mm}$ in diameter. The castor cake medium was moistened to $48.5 \%$ (w/w), and $6.25 \%$ molasses was added. Fermentation was carried out in laboratory-scale, tray-type bioreactors containing $20 \mathrm{~g}$ waste, forming a 1-cm deep layer in the bioreactor. The medium was inoculated with $10^{7} \mathrm{spores} / \mathrm{g}$ dry solid, and incubated in a climatic chamber with conditions set to $30^{\circ} \mathrm{C}$ and $90 \%$ water saturation. The fermentation samples (whole trays) were removed at 24-h intervals for up to $96 \mathrm{~h}$.

\section{Enzyme extraction}

After different periods of fermentation (24, 48, and 72 h), $100 \mathrm{mM}$ phosphate buffer, $\mathrm{pH} 7.0(5 \mathrm{~mL} / \mathrm{g})$ was added to each tray containing the fermented solids, and enzyme extraction was performed in a rotary shaker at $35^{\circ} \mathrm{C}$ and $200 \mathrm{rpm}$ for $20 \mathrm{~min}$. Next, a solid-liquid separation was obtained by pressing the cake followed by centrifugation at $2000 \mathrm{~g}$ for $5 \mathrm{~min}$ (21). The pressed solids were retained for protein extraction in order to determine their toxic composition after solid-state fermentation (SSF). The supernatant was stored at $-20^{\circ} \mathrm{C}$ and later used to determine protease activity.

\section{Protease activity}

Protease activity was determined by the method described by Charney and Tomarelli (22), which is based on the release of colored peptides derived from the digestion of azocasein. Samples were diluted in $50 \mathrm{mM}$ acetate buffer, $\mathrm{pH} 5.0$, and $0.5 \mathrm{~mL} 0.5 \%$ azocazein solution was added. Reaction was carried out for $40 \mathrm{~min}$ at $37^{\circ} \mathrm{C}$ and stopped by adding $0.5 \mathrm{~mL} 10 \%$ trichloroacetic acid. After centrifugation at $2000 \mathrm{~g}$ for $2 \mathrm{~min}$, the absorbance of the supernatant was determined at $428 \mathrm{~nm}$. One unit of protease activity was defined as the amount of enzyme activity causing one absorbance unit difference between the sample and its corresponding blank per minute under the assay conditions described. Enzyme activity is reported as units per gram of the initial dry solid medium.

\section{Treatment of castor cake with calcium compounds}

The castor cake $(0.3 \mathrm{~g} / \mathrm{mL})$ and the isolated $2 \mathrm{~S}$ albumin $(1.0 \mathrm{mg} / \mathrm{mL})$ were mixed with 4 or $8 \%$ calcium hydroxide $\left(\mathrm{Ca}(\mathrm{OH})_{2}\right)$, calcium carbonate $\left(\mathrm{CaCO}_{3}\right)$ or calcium oxide $(\mathrm{CaO})$. The calcium compounds were dissolved in PBS, $\mathrm{pH}$ 7.0. The treated castor cake or $2 \mathrm{~S}$ albumin were held at $25^{\circ} \mathrm{C}$ for $8 \mathrm{~h}$. The toxicity of the cake was evaluated by counting Vero cells and measuring LDH activity. The allergenic activity was determined in a mast cell degranulation assay as described below.

\section{Cytotoxicity assay}

Proteins from the fermented and chemically treated castor cake were extracted into PBS, pH 7.0 (1:4). The mixture was shaken for $3 \mathrm{~h}$ at $20^{\circ} \mathrm{C}$, followed by centrifugation at $12,000 \mathrm{~g}$ for $15 \mathrm{~min}$. Samples were filtered and then incubated with cells at a concentration of $10 \mu \mathrm{g} / \mathrm{mL}$. Each incubation was performed in triplicate. Cell death was measured by counting cells and by determining LDH activity.

\section{Allergy evaluation - mast cell degranulation assay}

Animals and antiserum. Isogenic female R/A Tor rats weighing $150 \mathrm{~g}$ were obtained from the animal house of Universidade Federal Fluminense (UFF), Niterói, RJ, Brazil. All experimental procedures were approved by the animal Research Ethics Committee of UFF. Rats were injected subcutaneously with $10 \mathrm{mg} 2 \mathrm{~S}$ albumin in the presence of $5 \mathrm{mg} \mathrm{Al} 2(\mathrm{OH})_{3}$, and $5 \mathrm{mg}$ nigrosin, which were used as adjuvants. After 15 days, rats were anesthetized and bled by cardiac puncture. The sera were pooled and tested in a mast cell degranulation assay (20).

Rat peritoneal mast cells. Wistar rats were obtained from the animal house of Universidade Estadual do Norte Fluminense Darcy Ribeiro (UENF). All experimental procedures were approved by the animal Research Ethics Board of UENF (Protocol 112). Mast cells were isolated as described by Deus-de-Oliveira et al. (23). The rats ( 250 g) were euthanized with $\mathrm{CO}_{2}$ and a peritoneal wash was performed by injecting $20 \mathrm{~mL}$ DMEM containing $12 \mathrm{U} / \mathrm{mL}$ heparin. The abdomen was gently massaged for approximately $90 \mathrm{~s}$. The peritoneal cavity was carefully opened, and the fluid containing peritoneal cells was aspirated using a Pasteur pipette. The cells were then transferred to Petri dishes and incubated for $30 \mathrm{~min}$ at $37^{\circ} \mathrm{C}$. Two-thirds of the upper supernatant was aspirated and discarded. The supernatant enriched with mast cells $\left(1.8 \times 10^{5}\right.$ mast cells/ $\mathrm{mL}$ ) was separated into aliquots of $100 \mathrm{~mL}$ in Eppendorf tubes and stored at room temperature.

Mast cell degranulation assays. Rat peritoneal mast cells $(100 \mu \mathrm{L})$ were incubated with rat preimmune serum as a control and initially activated for $60 \mathrm{~min}$ at $37^{\circ} \mathrm{C}$ with $2 S$ albumin polyclonal anti-rat IgE (2S alb AR IgE). After sensitization with $2 S$ alb AR IgE, cells were washed twice with DMEM. Each of these experiments was carried out in the presence or absence of the $2 S$ albumin pool (100 ng) and castor cake. After incubation with antibodies and potential allergens ( $2 S$ albumin or castor cake), mast cell degranulation and histamine content were determined as described by Deus-de-Oliveira et al. (23).

Briefly, the cells (in $10 \mu \mathrm{L}$ ) were stained for $15 \mathrm{~min}$ with $10 \mu \mathrm{L} 0.1 \%$ toluidine blue, $10 \%$ formaldehyde, and $1 \%$ acetic acid, $\mathrm{pH} 2.8$, allowing the visualization of degranulated mast cells. The granulated and degranulated mast cells were counted under a light microscope using a 40X objective in a Neubauer chamber. For histamine quantifi- 
cation, after incubation with antibodies and allergens, the cell suspensions $(100 \mu \mathrm{L})$ were centrifuged at $170 \mathrm{~g}$ for 10 $\min$. An aliquot of the supernatant $(20 \mu \mathrm{L})$ was removed for histamine detection. After ion-exchange chromatography, the histamine released was quantified as a post-columno-phthaldialdehyde derivative (23).

\section{Results}

\section{Cytotoxicity assay}

Ricin purification was confirmed by $12 \%$ SDS-PAGE and by partial $\mathrm{N}$-terminal sequencing using Edman degradation (lle-Phe-Pro-GIn-Tyr-Pro-Met-Lys) (data not shown).

Agradual reduction in the number of living cells (Figure 1A) was observed during the first few hours of exposure to purified ricin, and after $48 \mathrm{~h}$ of incubation, the cell concentration had declined by approximately $90 \%$, leaving just a few units still attached to the substrate (Figure 1A and B). Co-administration of an anti-ricin A chain antibody with the toxin allowed the treated cells to grow, mimicking the negative control (PBS pH 7.0; Figure $1 \mathrm{~A}$ and $\mathrm{B}$ ). The microscopic images of Vero cells treated for $48 \mathrm{~h}$ with $\mathrm{PBS}$, ricin or ricin and $\lg \mathrm{G}$, shown in Figure 1B, illustrate these results. We also used a lactate dehydrogenase activity assay to evaluate toxicity under the same treatment conditions as in Figure $1 \mathrm{~A}$ and $\mathrm{B}$ and obtained similar results (Figure $1 \mathrm{C}$ ).

To determine the lethal dose of ricin, a dose-response curve was generated. The limit of detection of the Vero cell assay was $10 \mathrm{ng}$ ricin/mL using a concentration of $1.6 \mathrm{x}$ $10^{5}$ cells/well (Figure $2 A$ and $B$ ). This concentration of ricin reduced the number of cells by approximately $25 \%$ after 12 and $24 \mathrm{~h}$ of exposure and by approximately $50 \%$ after 48 h. When $1.6 \times 10^{5}$ cells were treated with 100 or $10 \mu \mathrm{g} / \mathrm{mL}$ ricin, $100 \%$ cell death was observed after $48 \mathrm{~h}$ of incubation; concentrations of less than $1 \mathrm{ng} / \mathrm{mL}$ were considered to be nontoxic (Figure $2 \mathrm{~A}$ and $\mathrm{B}$ ).

\section{Solid-state fermentation}

The presence of ricin was first evaluated by $12 \%$ SDSPAGE (Figure 3A). We observed that proteins with molecular weights similar to those of the ricin $A$ and $B$ chains (29 and $34 \mathrm{kDa}$, respectively) were degraded at each time of fermentation (24, 48, 72, and $96 \mathrm{~h}$ ). An increase in the number of protein spots under $30 \mathrm{kDa}$ was also noted.

The SSF process eliminated the toxicity of the castor
A

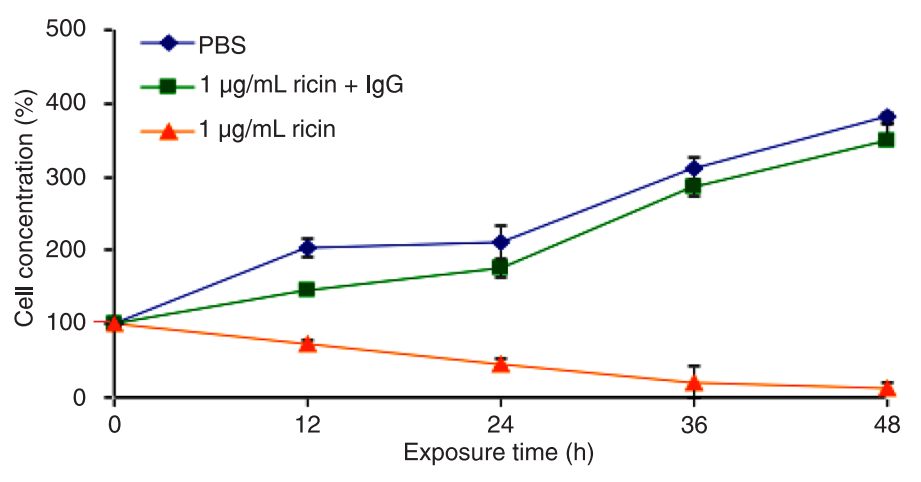

C

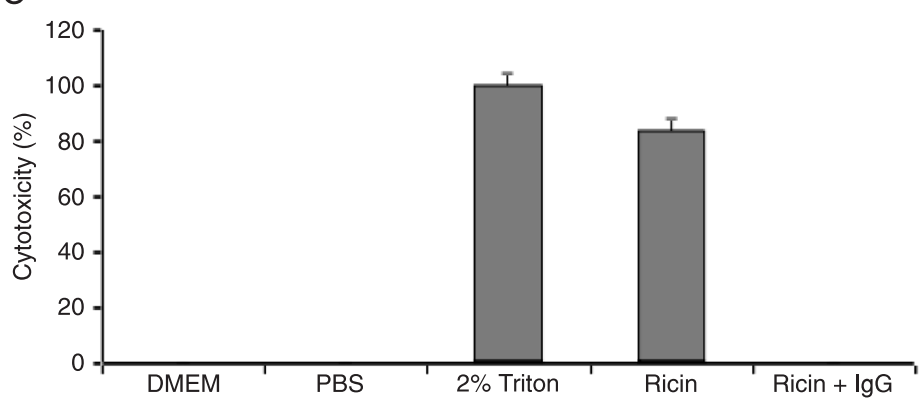

B

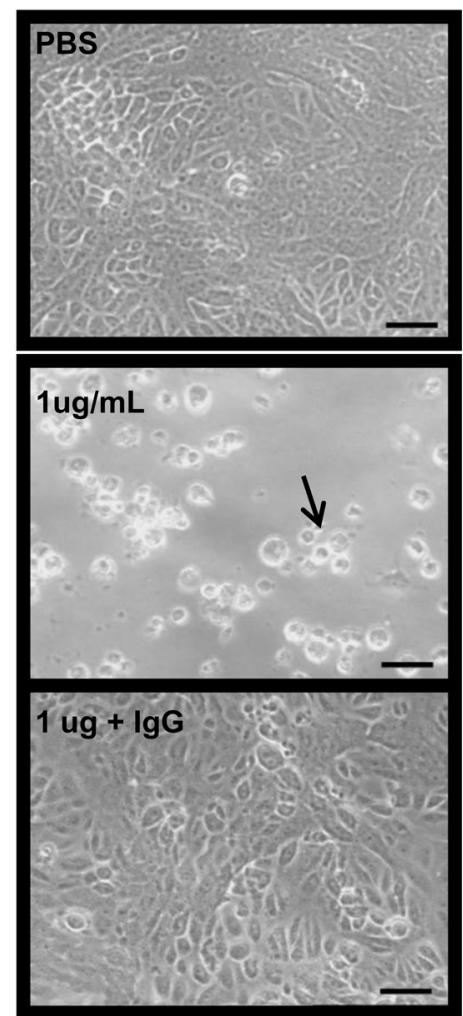

Figure 1. Cytotoxicity of ricin. $A$, Kinetics of cell growth (cell concentration estimated by cell counting) after treatment with PBS (pH 7.0, control), $1 \mu \mathrm{g} / \mathrm{mL}$ ricin and $1 \mu \mathrm{g} / \mathrm{mL}$ ricin plus anti-ricin antibody $(\mathrm{lgG})$. B. Microscopy of cell cultures $48 \mathrm{~h}$ after treatment. Vero cells (arrow) loose spread distribution and compact monolayer architecture (bar $=50 \mu \mathrm{m}$ ). $C$, Cytotoxicity measured using a lactate dehydrogenase assay (positive control: $2 \%$ Triton). 
cake. Cells incubated in the presence of cake that had been fermented for 12, 24, or $48 \mathrm{~h}$ grew normally. These results were confirmed by the absence of LDH activity. After $48 \mathrm{~h}$ of fermentation, we observed a slight inhibition of cell growth (Figure 3B), which was accompanied by a low level of $\mathrm{LDH}$ release. To evaluate whether this effect was associated with residual toxic activity of ricin we used an antibody to the ricin-A chain in order to immunoprecipitate the protein. The toxic effect remained, indicating that it was not associated with the presence of ricin.

Protease activity was measured at each fermentation time and a maximum activity of $1.2 \mathrm{U} / \mathrm{g}$ was observed after $48 \mathrm{~h}$ of fermentation.

\section{Calcium treatment}

Castor cake detoxification by chemical treatment. The growth of Vero cells exposed to the castor cake treated with 4 or $8 \%$ of various calcium compounds for 24 or $48 \mathrm{~h}$ is presented in Figure 4A and B. Calcium carbonate was not effective in detoxifying
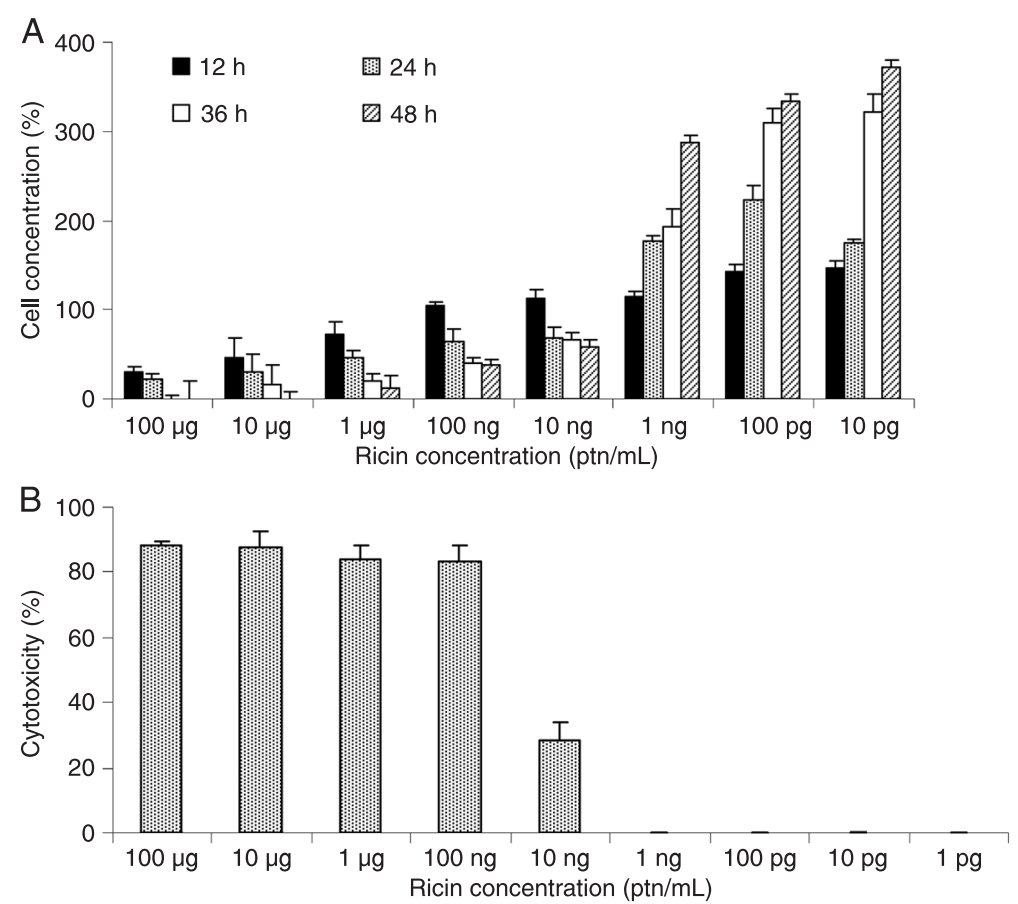

Figure 2. Limit of detection of ricin in a Vero cell culture. A, Cell concentration (estimated by cell counting) after treatment with different quantities of ricin. $B, C y-$ totoxicity measured using a lactate dehydrogenase assay. ptn $=$ protein.
A

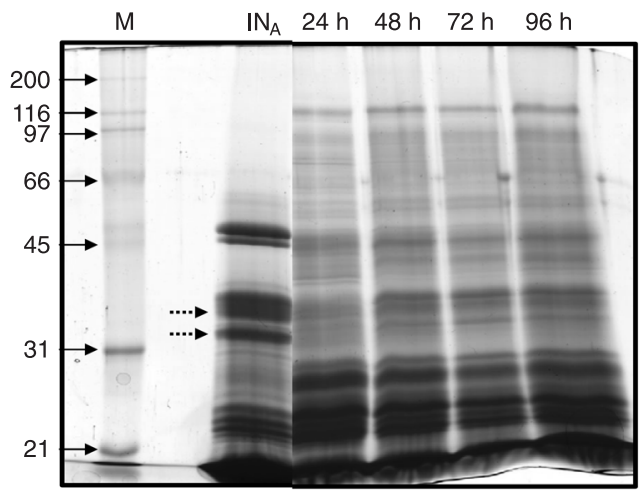

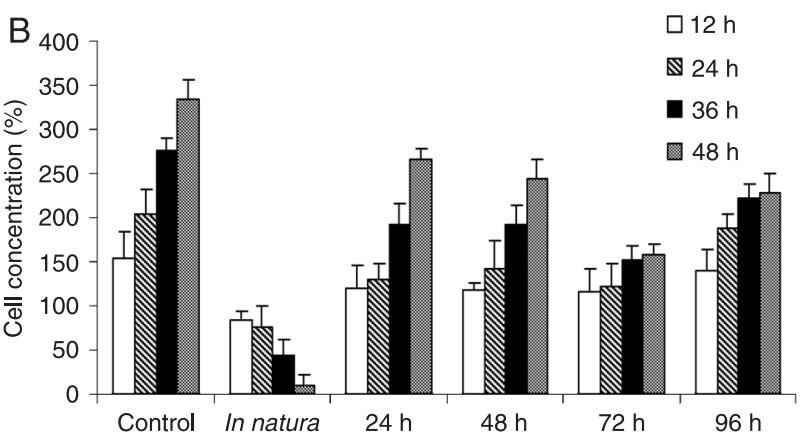

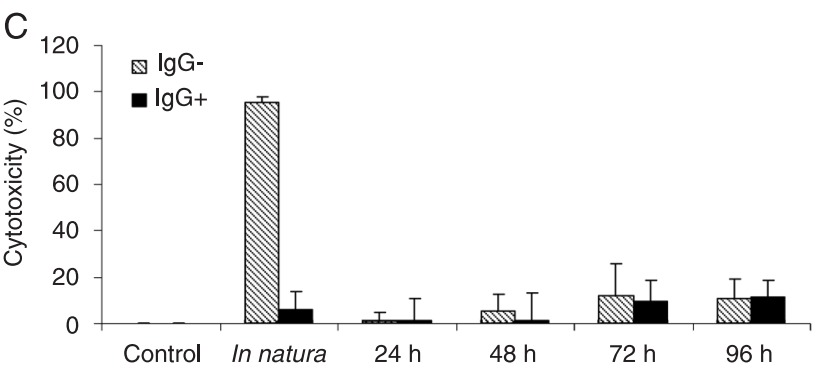

Figure 3. Toxicity of the fermented castor cake. A, SDS-PAGE (12\%) of proteins extracted from in natura $\left(\mathrm{IN}_{\mathrm{A}}\right)$ and fermented $(24,48,72$, and $96 \mathrm{~h}$ ) castor cake. Lane $\mathrm{M}=$ DNA marker. Twenty micrograms of protein was loaded in each lane. $B$, Cell concentration estimated by cell counting after cell growth for 12, 24, 36, and $48 \mathrm{~h}$. Control cells = cells grown in DMEM; In natura = cells grown in the presence of castor crude cake; $24,48,72$, and $96 \mathrm{~h}=$ times of fermentation (cells grown in the presence of fermented cake). $C$, Cytotoxicity of fermented cake incubated or not with ricin anti-A chain antibody (IgG+ and lgG-, respectively) measured using a lactate dehydrogenase activity assay. 


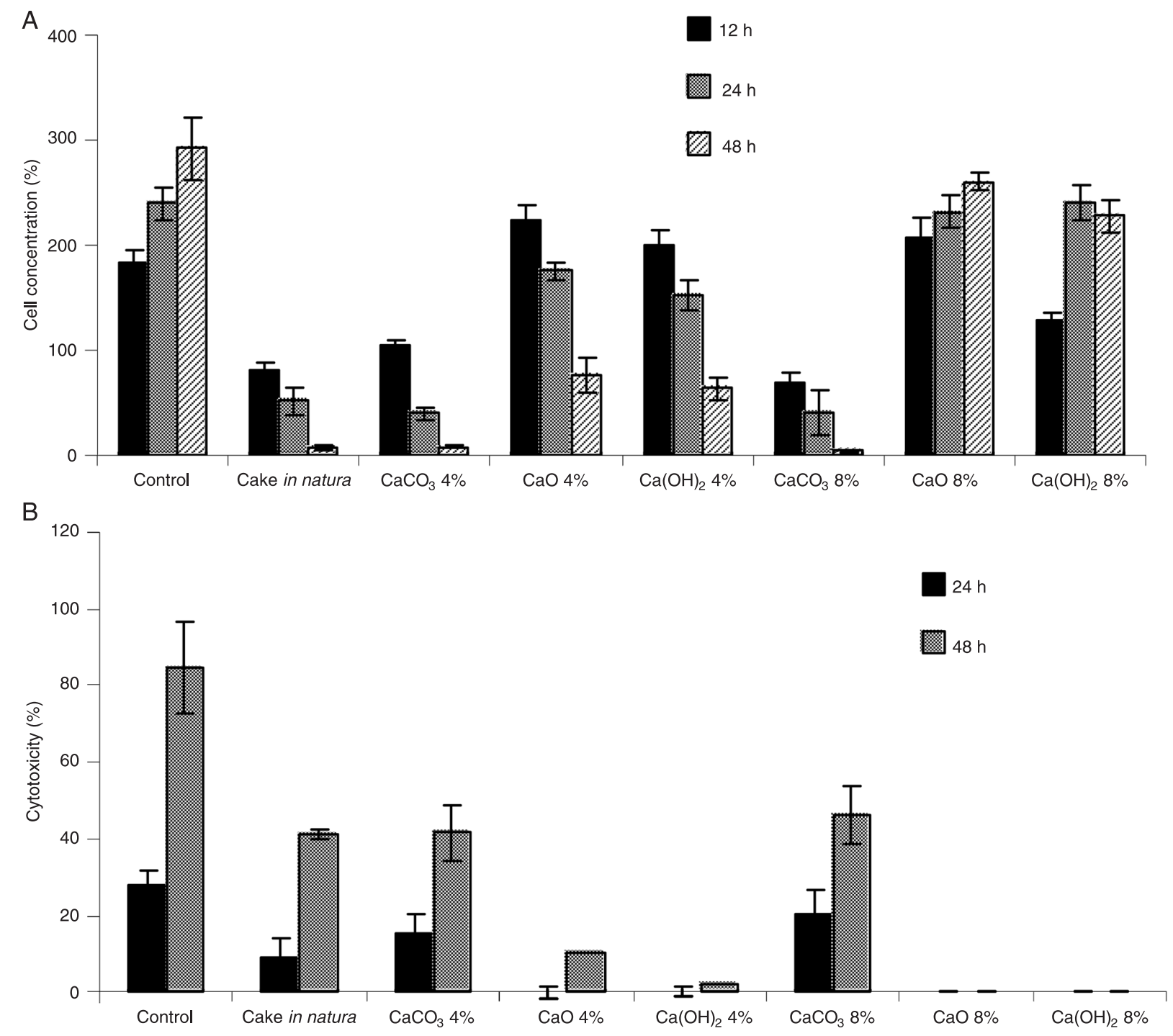

Figure 4. Toxicity of chemically treated castor cake. $A$, Vero cell viability. The initial cell concentration was $1.6 \times 10^{5}$ cells $/$ well $(100 \%)$. PBS, $\mathrm{pH}$ 7.0, was used as a negative control and crude in natura castor cake protein extract as a positive control. $B$, Lactate dehydrogenase activity in Vero cells incubated with castor cake treated with 4 or $8 \% \mathrm{CaCO}_{3}, \mathrm{CaO}$, or $\mathrm{Ca}(\mathrm{OH})_{2}$ at a ratio of $1: 1(\mathrm{v} / \mathrm{v})$. Data are representative of experiments performed in triplicate.

the castor cake. The cells did not proliferate in the presence of the treated cake. On the other hand, normal proliferation of Vero cells was observed when the castor cake was treated with $8 \%$ calcium oxide or calcium hydroxide (Figure $4 \mathrm{~A}$ ). The results of the LDH assay (Figure $4 \mathrm{~B}$ ) confirmed the cell counting data (Figure 4A).

Inactivation of castor seed allergens by calcium treatment. Because of the importance of negatively charged residues for IgE-binding, we treated the isolated $2 \mathrm{~S}$ albumin and castor cake with a calcium compound $\left[\left(\mathrm{Ca}(\mathrm{OH})_{2}, \mathrm{CaO}\right.\right.$, or $\mathrm{CaCO}_{3}$ ] to neutralize these charges. The normal extent of mast cell degranulation observed during the isolation of these cells was $\sim 30 \%$ (Figure $5 \mathrm{~A}$, column 1 ), and the mast cell degranulation induced by challenge with $2 S$ albumin was $\sim 70 \%$ (Figure $5 \mathrm{~A}$, column 2 ). Treatment of $2 \mathrm{~S}$ albumin with calcium ions reduced the mast cell degranulation to $30-40 \%$ (Figure 5B). The decrease of mast cell degranulation was also observed when the castor cake was treated with these compounds (Figure 5C).

\section{Discussion}

Ricinus communis is a plant of economic importance because of the extensive potential uses of the oil extracted from its seeds. After making castor oil, the by-product is a residual cake, which can be used as a fertilizer and even 

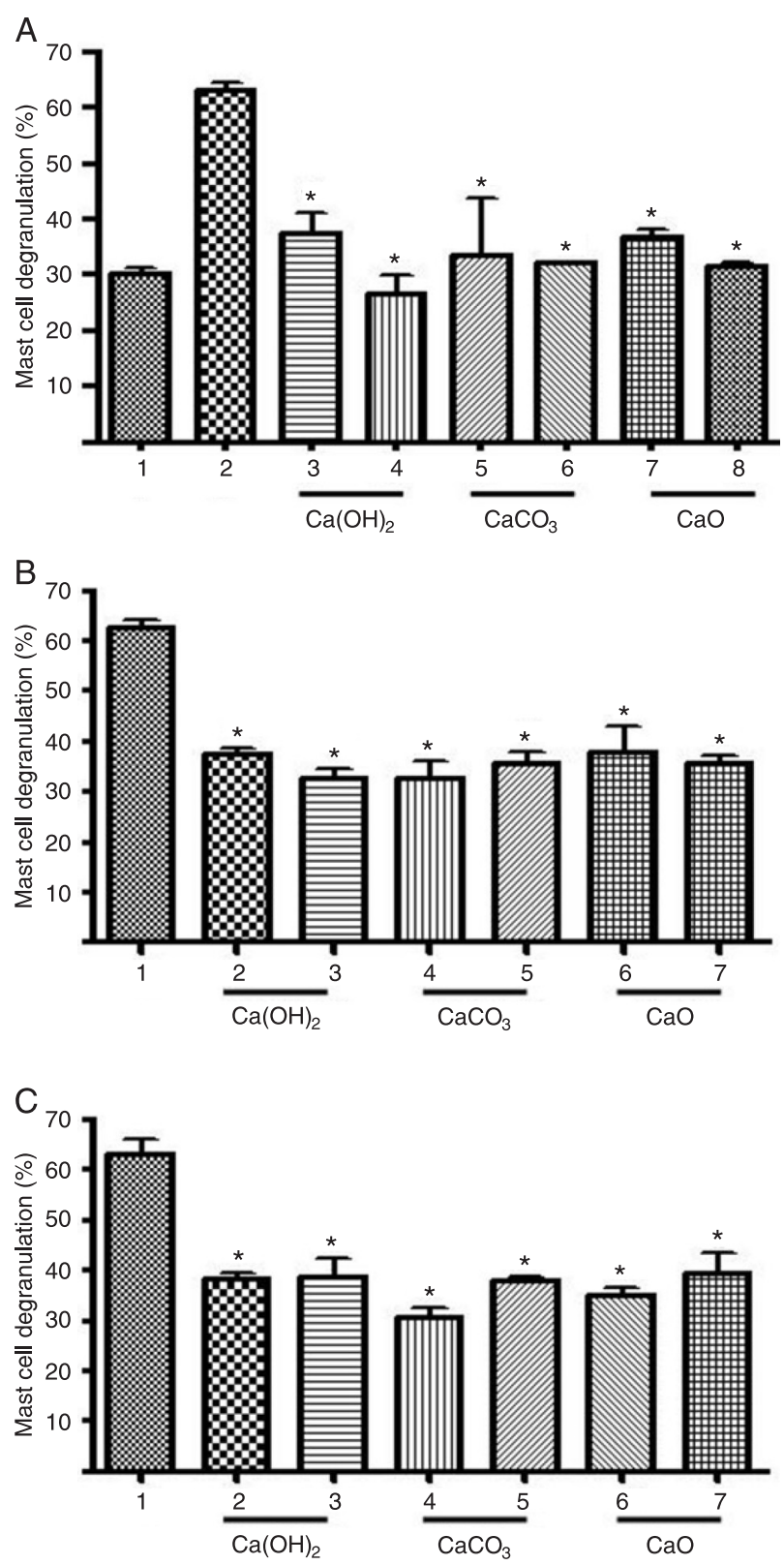

Figure 5. Mast cell degranulation after calcium treatment. $A, 1$ $=$ Control cells; 2 = $2 \mathrm{~S}$ albumin pool plus $2 \mathrm{~S}$ albumin antiserum; $3-8=4 \% \mathrm{Ca}(\mathrm{OH})_{2} ; 8 \% \mathrm{Ca}(\mathrm{OH})_{2} ; 4 \% \mathrm{CaCO}_{3} ; 8 \% \mathrm{CaCO}_{3} ; 4 \%$ $\mathrm{CaO} ; 8 \% \mathrm{CaO}$ plus $2 \mathrm{~S}$ albumin serum, respectively. $\mathrm{B}, 1=$ native $2 S$ albumin pool plus $2 S$ albumin antiserum; $2-7=2 S$ albumin treated with $4 \% \mathrm{Ca}(\mathrm{OH})_{2} ; 8 \% \mathrm{Ca}(\mathrm{OH})_{2} ; 4 \% \mathrm{CaCO}_{3} ; 8 \% \mathrm{CaCO}_{3}$; $4 \% \mathrm{CaO}$, and $8 \% \mathrm{CaO}$ (2S albumin serum included in all samples). $\mathrm{C}, 1=$ castor cake plus $2 \mathrm{~S}$ albumin antiserum; $2-7=$ castor cake treated with $4 \% \mathrm{Ca}(\mathrm{OH})_{2} ; 8 \% \mathrm{Ca}(\mathrm{OH})_{2} ; 4 \% \mathrm{CaCO}_{3} ; 8 \%$ $\mathrm{CaCO}_{3} ; 4 \% \mathrm{CaO} ; 8 \% \mathrm{CaO}$ (2S albumin serum included in all samples). Data are reported as means \pm SD for 3 experiments (mast cell preparations from different rats). ${ }^{*} P<0.001$ compared to positive control (one-way ANOVA followed by the Tukey test). in animal feed after the deactivation of toxins. Although various processes intended to eliminate ricin have already been described, many of these methods are too expensive for widespread use. In addition, there is no biological assay standardized to evaluate most of these detoxification methods (8). The objectives of the present study were 1) to standardize a bioassay to detect the presence and activity of ricin in castor bean cakes, and 2) to use low-cost methods to detoxify and inactivate allergens in castor cakes.

In order to achieve our first objective, we inoculated Vero cell cultures with various concentrations of purified toxin, and the number of living cells was determined by counting every $24 \mathrm{~h}$ after inoculation. Cytotoxicity was also evaluated by measuring LDH activity (24). To confirm the specific toxic activity of ricin, we immunoprecipitated this protein using an anti-ricin (A-chain specific) antibody. We showed that co-administration of the antibody along with the toxin in cell culture alleviated the toxic effects of ricin. This result is most likely caused by antibody-mediated blockage of the A-chain active site, which eliminates the toxic activity of ricin by preventing the enzyme from binding to its substrate (25). It was also recently shown that treatment of RAW264.7 cells with anti-ricin A-chain antibodies significantly increased cell viability when the antibodies were added either before or after ricin exposure (26) protecting the cells against ricin ribotoxicity in cell-based luciferase and cell cytotoxicity assays.

The minimum level of ricin detected by the proposed assay was $10 \mathrm{ng} / \mathrm{mL}$. Other methods described in the literature are more sensitive and can detect the protein ricin at lower concentrations. One example is immuno-PCR (14), which combines the specificity of immunological analysis with the exponential amplification of PCR and can detect ricin at concentrations as low as $0.01 \mathrm{pg} / \mathrm{mL}$. However, this and many other tests based on antibody binding cannot reliably evaluate the toxic activity of the protein. Moreover, PCR kits are expensive, and large-scale use of the method may be impractical. A similar test using Jurkat cells showed a toxic effect of $100 \mathrm{pg} / \mathrm{mL}$ ricin (20). However, the test only evaluated toxicity by determining LDH activity, as Jurkat cells are an adherent strain, which makes them difficult to count. The advantage of the current method is that it can be used in laboratories equipped for either cell counting or the measurement of LDH activity.

Two methods were used to detoxify the castor bean cake. The first method was SSF. The ricin cytotoxicity was reduced to $<2 \%$ after $24 \mathrm{~h}$ of fermentation. In this assay, cells were incubated with fermented cake, whose total protein content was $10 \mu \mathrm{g} / \mathrm{mL}$ (approximately $0.4 \mu \mathrm{g} / \mathrm{mL}$ ricin). This amount of ricin is 40 times higher than that considered to be toxic to the cell. Thus, we have shown the efficiency of the SSF to inactivate cytotoxicity activity of ricin. However, after 72 $\mathrm{h}$ of fermentation, a slight inhibition of cell growth was still observed. The administration of anti-ricin A-chain antibody 
to treated cells showed that ricin was not responsible for the toxicity observed at 72 and $96 \mathrm{~h}$ of fermentation. One possible explanation is that the $A$. nigermay have produced a toxic compound. Although considered a GRAS organism, some strains of $A$. niger can produce ochratoxin A (OTA), although at low concentrations (27). The possible production of OTA does not preclude the use of this methodology because, as shown, the elimination of toxic activity occurred in the first $24 \mathrm{~h}$ of fermentation and the formation of the toxin, if any, was only after $48 \mathrm{~h}$. Complete ricin degradation was also achieved in a previous study by growing $P$. simplicissimum using castor bean waste as substrate to produce lipase (9).

The other method used for castor cake detoxification was chemical treatment with calcium compounds. We chose to employ calcium compounds to deactivate the allergenic epitopes after the identification of the importance of negative amino acids in the IgE epitope (23). These compounds are GRAS/FS (substances generally recognized as safe in foods but limited in standardized foods). Calcium salts are available at low cost, are important for improving the quality of some animal foods and are among the main mineral additives in the preparation of feed for different groups of animals, including cattle (28). Based on the results of the cytotoxicity assay, we determined that this treatment was efficient given that two of the compounds (calcium oxide

\section{References}

1. Akhtar M, Alam MM. Utilization of waste materials in nematode control: A review. Bioresource Technol 1993; 45: 1-7.

2. Stirpe F, Battelli MG. Ribosome-inactivating proteins: progress and problems. Cell Mol Life Sci 2006; 63: 1850-1866.

3. Leshin J, Danielsen M, Credle JJ, Weeks A, O'Connell KP, Dretchen K. Characterization of ricin toxin family members from Ricinus communis. Toxicon 2010; 55: 658-661.

4. Montanaro L, Sperti S, Stirpe F. Inhibition by ricin of protein synthesis in vitro. Ribosomes as the target of the toxin. Biochem J 1973; 136: 677-683.

5. Endo $\mathrm{Y}$, Tsurugi K. RNA N-glycosidase activity of ricin A-chain. Mechanism of action of the toxic lectin ricin on eukaryotic ribosomes. J Biol Chem 1987; 262: 8128-8130.

6. Olsnes S, Fernandez-Puentes C, Carrasco L, Vazquez D. Ribosome inactivation by the toxic lectins abrin and ricin. Kinetics of the enzymic activity of the toxin A-chains. Eur $\mathrm{J}$ Biochem 1975; 60: 281-288.

7. Audi J, Belson M, Patel M, Schier J, Osterloh J. Ricin poisoning: a comprehensive review. JAMA 2005; 294: 23422351.

8. Anandan S, Anil Kumar GK, Ghosh J, Ramachandra KS. Effect of different physical and chemical treatments on detoxification of ricin in castor cake. Anim Feed Sci Technol 2005; 120: 159-168.

9. Godoy MG, Gutarra MLE, Maciel FM, Felix SP, Bevilaqua JV, Machado OLT, et al. Use of a low-cost methodology for biodetoxification of castor bean waste and lipase production. Enzyme Microb Technol 2009; 44: 317-322. and calcium hydroxide) were able to inactivate ricin. The treatments using calcium compounds also reduced mast cell degranulation induced by the $2 \mathrm{~S}$ albumin pool or the crude cake from $70 \%$ to approximately $30 \%$ of the value observed in the negative controls. Based on these data, we conclude that the technology developed here works to reduce degranulation of mast cells.

In conclusion, considering that biological assays are important to detect the actual toxicity of ricin, the present study provided an option to perform a measurement of the toxic activity of ricin. The Jurkat cell used by Brzezinski et al. (20), becomes an unstable sensor to detect toxic cell effects; however, the Vero cell line has been widely used for screening for the toxic product (abiotic or biotic), maintaining cell organelles characteristics and stable structure.

Moreover, we demonstrated that SSF and treatment with calcium compounds were effective for both the inactivation of allergens and the detoxification of castor cake, reducing the risk of handling and generating a product that could be included in animal feed.

\section{Acknowledgments}

This research was supported by FINEP, CNPq and FAPERJ.

10. Severino LS, Auld DL, Baldanzi M, Candido MJD, Chen G, Crosby W, et al. A review on the challenges for increased production of castor. Agronomy J 2012; 104: 853-880.

11. Godal A, Fodstad O, Ingebrigtsen K, Pihl A. Pharmacological studies of ricin in mice and humans. Cancer Chemother Pharmacol 1984; 13: 157-163.

12. Neal LM, O'Hara J, Brey RN III, Mantis NJ. A monoclonal immunoglobulin $\mathrm{G}$ antibody directed against an immunodominant linear epitope on the ricin A chain confers systemic and mucosal immunity to ricin. Infect Immun 2010; 78: 552561.

13. Shyu HF, Chiao DJ, Liu HW, Tang SS. Monoclonal antibodybased enzyme immunoassay for detection of ricin. Hybrid Hybridomics 2002; 21: 69-73.

14. Lubelli C, Chatgilialoglu A, Bolognesi A, Strocchi P, Colombatti M, Stirpe F. Detection of ricin and other ribosome-inactivating proteins by an immuno-polymerase chain reaction assay. Anal Biochem 2006; 355: 102-109.

15. Anderson GP, Nerurkar NL. Improved fluoroimmunoassays using the dye Alexa Fluor 647 with the RAPTOR, a fiber optic biosensor. J Immunol Methods 2002; 271: 17-24.

16. Sharief FS, Li SS. Amino acid sequence of small and large subunits of seed storage protein from Ricinus communis. $J$ Biol Chem 1982; 257: 14753-14759.

17. Irwin SD, Keen JN, Findlay JB, Lord JM. The Ricinus communis $2 \mathrm{~S}$ albumin precursor: a single preproprotein may be processed into two different heterodimeric storage proteins. Mol Gen Genet 1990; 222: 400-408. 
18. Machado OL, Silva Junior JG. An allergenic $2 S$ storage protein from Ricinus communis seeds which is a part of the $2 \mathrm{~S}$ albumin precursor predicted by c-DNA data. Braz J Med Biol Res 1992; 25: 567-582.

19. Bashir ME, Hubatsch I, Leinenbach HP, Zeppezauer M, Panzani RC, Hussein IH. Ric c 1 and Ric c 3, the allergenic $2 S$ albumin storage proteins of Ricinus communis: complete primary structures and phylogenetic relationships. Int Arch Allergy Immunol 1998; 115: 73-82.

20. Brzezinski JL, Craft DL. Evaluation of an in vitro bioassay for the detection of purified ricin and castor bean in beverages and liquid food matrices. J Food Prot 2007; 70: 2377-2382.

21. Gombert AK, Pinto AL, Castilho LR, Freire DMG. Lipase, amylase and protease production by Penicillium restrictum in a solid-state fermentation using babassu oil cake. Process Biochem 1999; 35: 85-90.

22. Charney J, Tomarelli RM. A colorimetric method for the determination of the proteolytic activity of duodenal juice. $J$ Biol Chem 1947; 171: 501-505.

23. Deus-de-Oliveira N, Felix SP, Carrielo-Gama C, Fernandes KV, DaMatta RA, Machado OL. Identification of critical amino acids in the IgE epitopes of Ric c 1 and Ric c 3 and the ap- plication of glutamic acid as an IgE blocker. PLoS One 2011; 6: e21455

24. Sandvig K, Bergan J, Dyve AB, Skotland T, Torgersen ML. Endocytosis and retrograde transport of Shiga toxin. Toxicon 2010; 56: 1181-1185.

25. Chang MS, Houston LL. Effect of ribosome treatment on sensitivity to ricin A chain ming-shi chang and I.I. houston. Biochem Biophys Res Commun 1981; 101: 1402-1409.

26. Wu F, Fan S, Martiniuk F, Pincus S, Muller S, Kohler H, et al. Protective effects of anti-ricin A-chain antibodies delivered intracellularly against ricin-induced cytotoxicity. World J Biol Chem 2010; 1: 188-195.

27. Esteban A, Abarca ML, Bragulat MR, Cabanes FJ. Study of the effect of water activity and temperature on ochratoxin $A$ production by Aspergillus carbonarius. Food Microbiol 2006; 23: $634-640$.

28. Abbeddou S, Riwahi S, Iniguez L, Zaklouta M. Hess H. Ruminal degradability, digestibility, energy content, and influence on nitrogen turnover of various Mediterranean byproducts in fat-tailed Awassi sheep. Anim. Feed Sci. Technol 2011; 163: 99-110. 